\title{
INSTITUTIONS, MARKETS AND GROWTH: A THEORY OF COMPARATIVE CORPORATE GOVERNANCE
}

Kose John

Stern School of Business

New York University

Tel: (212) 9980337

E-mail: kjohn@stern.nyu.edu

\author{
Simi Kedia \\ College of Business \\ Rutgers University \\ Tel: (973)353-1145 \\ E-mail: skedia@rbmail.rutgers.edu
}

This Draft: November 2006

\begin{abstract}
Two different financial systems with some opposing features have evolved in the advanced economies, namely the insider system and the outsider system. In this paper, we provide a theoretical framework where the features of the optimal governance system are derived as a function of economy-wide parameters, such as the degree of development of markets and the quality of the institutions, and firm-specific parameters, such as the productivity of its technology. Our results include the following: (1) For a degree of relative development of markets below a threshold, internal governance systems dominate for all firms in the economy independent of productivity, (2) When the development of markets in an economy is above that threshold, either system may emerge as optimal depending on the productivity of the technology. There are marked differences in the residual agency costs under the two systems when the scale of investment is large. It is shown that insider systems constitute the optimal governance system for technologies that are optimally implemented at a small scale while outsider systems dominate for technologies that are optimally implemented at large scales. These results provide a new argument for the potential convergence towards outsider systems based on technological growth.
\end{abstract}




\section{INSTITUTIONS, MARKETS AND GROWTH: A THEORY OF COMPARATIVE CORPORATE GOVERNANCE}

The differences among the corporate governance systems of the advanced economies of the world have attracted a lot of attention from financial economists, legal scholars, and policy makers ${ }^{1}$. Two different financial systems with some opposing features seem to have evolved in the advanced economies, namely the insider system and the outsider system. There are distinctive differences among these systems with regard to ownership, control, and capital markets. Countries belonging to the insider system (e.g., France, Germany and Italy) exhibit high levels of ownership concentration, illiquid capital markets, and a high degree of crossholdings. Widely dispersed ownership, liquid stock markets, low level of inter-corporate crossholdings and an active market for corporate control are the main features of the outsider system (e.g., U.K. and U.S). The existence and persistence of these markedly different corporate governance systems have been the subject of an active debate in the area. ${ }^{2}$ With new and emerging economies searching for the right corporate governance, the debate on the relative efficiency of the different existing governance systems has attained enormous importance.

It has been conventional to take existence of these systems as given and compare their properties and efficiency. In this paper, we develop a theoretical framework where the features of the optimal governance systems are derived as a function of economy wide parameters, such as the degree of development of markets and the quality of the institutions, and firm-specific

\footnotetext{
${ }^{1}$ The academic literature in law, economics, finance, strategy, and management on corporate governance has become extensive. For recent surveys, see Shleifer and Vishny (1997), John and Senbet (1998), and Bradley, Shipani, Sundaram and Walsh (1999).

${ }^{2}$ The terms used by researchers to highlight the differences among different systems of corporate governance has varied. See Erik Berglof (1997). The most prominent dichotomization has been insider vs outsider systems. Other
} 
parameters such as the productivity of its technology. The optimal systems that we obtain map into the insider and outsider systems. Our analysis explains the optimal choice between these systems with a view to studying their evolution and persistence.

There is increasing empirical evidence on the differences in corporate governance among countries. In a series of influential papers La Porta et al. $(1997,1998,1999,2002)$ have argued that the extent of legal protection of outside investors from expropriation of outsider shareholders or managers, is an important determinant of these differences. Recent empirical work shows that better legal protection of outside shareholders is associated with lower concentration of ownership and control, more valuable stock markets, higher number of listed firms and higher valuation of listed firms relative to their assets. ${ }^{3}$ Studies have also documented a link between corporate valuation and corporate governance mechanisms other than investor protection. Gorton and Schmid (2000) show that higher ownership by the large shareholders is associated with higher valuation of assets in Germany. Gompers, Ishi and Metrick (2001) document that US firms in the top decile of a "governance index" constructed from provisions related to takeover defenses and shareholder rights earned significantly higher abnormal returns over those in the lowest decile. ${ }^{4}$

While the understanding of the empirical differences in the patterns of corporate governance has advanced in recent years, the theoretical work in this area is nascent. A number of studies attempt to explain theoretically why control is so concentrated with poor shareholder protection in a setting where alignment is the only viable mechanism of corporate governance

pairs of terms include "arms-length control-oriented ," Berglof (1997), "market-based-relationship-oriented” e.g., Kaplan (1994) and market-based bank-based, e.g., Edwards and Fischer (1994).

${ }^{3}$ See European Corporate Governance Network (1997), La Porta, Lopez- de-Silanes and Shleifer (1999); Claessens et al. $(2000,2002)$, La Porta et al. $(1997,1998,1999,2002)$.

${ }^{4}$ Other interesting evidence that relate differences in international corporate governance to growth, performance and capital allocation has been documented recently. See, e.g., the special issue on International Corporate Governance of the Journal of Financial Economics, Vol. 59, Nos. 1-2, October-November 2000. 
(Zingales (1995), La Porta et al. (1999), Bebchuk (1999)). La Porta et al. (2002) make the case for higher concentration of cash flow ownership with poor shareholder protection. Shleifer and Wolfenzon (2001) also study ownership concentration as a function of the quality of investor protection. The effectiveness of investor protection is modeled as the likelihood that the entrepreneur is caught and fined for expropriating shareholders. In a model, which allows for insider ownership as the only mechanism of corporate governance, they derive implications for the equilibrium ownership concentration and dividend payouts as a function of protection of shareholders available in a given country. In our model, we allow for takeovers as an additional mechanism of corporate governance whose effectiveness is linked to the degree of development of markets in an economy. Economies are characterized by two parameters, the quality of institutions available to enforce contracts and the degree of development of markets. In each economy, the optimal governance system and the scale of investment undertaken is endogenously determined. For a fixed scale of investment, John and Kedia (2000) study the design of an optimal governance system structured from three corporate governance mechanisms available, namely managerial ownership, monitored debt and disciplining by the takeover market. They allow for interaction among the mechanisms and show that in any optimal governance system: 1) monitored debt is accompanied by concentrated ownership, and 2) takeovers are accompanied by diffuse ownership. The optimal configurations that they derive correspond to the different corporate governance systems seen around the world.

A major objective of this paper is to study the optimality of governance structures and their relation to the underlying technology and its growth. In this paper, we provide a theory of changes in governance structure of firms in an economy based on growth in the underlying technology. This in turn provides a framework to examine potential convergence in the governance systems around the world based on technological growth in those economies. This 
growth-based theory of changes in governance systems is in contrast to other theories, which have been proposed in the literature, to explain the dynamics of governance systems around the world.

We have a simple stylized model of an entrepreneur who has access to an investment opportunity set which can be implemented at different scales of investment. We set up a generic agency problem, which influences the manager's investment decision. The entrepreneur's objective is to set up an optimal governance structure and choose the optimal scale of investment to maximize firm value net of agency costs. In putting together an optimal governance structure the entrepreneur has a choice over all possible combinations of two different governance mechanisms, namely managerial alignment and takeovers. The entrepreneur also takes into account the interactions between the two governance mechanisms and the characteristics of the embedding economy. In choosing the optimal scale of investment the entrepreneur not only takes into account the nature of the underlying technology but also the agency problems that arise at that scale of investment. The overall problem of the entrepreneur is effectively a joint decision regarding investment scale and governance structure to maximize firm value net of agency costs.

We start with a simple generic agency problem. Managers may choose a lower valued project because it yields them larger private benefits. The entrepreneur uses the mechanisms of corporate governance available and designs a corporate governance system, which minimizes the expected value loss from the manager choosing the lower valued project. The governance mechanisms available are 1) alignment of managerial incentives with that of shareholders, and 2) takeovers. ${ }^{5}$ The characteristics of the embedding economy influence the effectiveness of both the

\footnotetext{
${ }^{5}$ Although we do not model all of the corporate governance mechanisms possible we view managerial alignment and takeovers as representative of two groups of corporate governance mechanisms available. Managerial
} 
governance mechanisms. The embedding economy is characterized by the quality of institutions available in the economy $(\lambda)$ which affects the menu of admissible contracts, and hence the severity of the agency problems remaining after the contractual solutions have been exhausted. Similarly the degree of development of markets $(M)$ influences the effectiveness of takeovers. The technology is characterized by its productivity, $\eta$, which determines the optimal scale of investment at which the technology will be implemented. For increasing levels of investment undertaken, the agency problems under both governance mechanisms (and under their different combinations) increase at different rates. The optimal governance system is therefore determined jointly with the optimal scale of investment such that the firm value net of agency cost is maximized. ${ }^{6}$

The first set of results characterize the optimal governance structures that emerge. We show that the optimal governance structures have one of two forms: 1) dispersed ownership and an effective role for takeovers, 2) concentrated insider ownership with reliance on the existing financial institutions with little or no role for takeovers. The first governance system will be called an outsider system and the second governance system will be called an insider system. Although, a priori, a blend of the two governance mechanisms, managerial alignment and takeovers, could have been optimal, our result is that the optimal governance system will exclusively use one mechanisms or the other, along with the corresponding extremal (not interior) ownership structure.

ownership has the property of pre-commitment in that it aligns managerial decisions to be in the interests of shareholders in all situations except when the private benefits are too large. Other mechanisms that have a selfbinding or pre-commitment property belong to this group. These include committing to periodic audits, including monitoring rule in corporate charter or self-imposing debt covenants. The second group of mechanisms represented by takeovers act to implement the good project without the consent of the manager. These mechanisms can be thought of as interventionists mechanisms and include also outside large shareholder activism and creditor intervention in bankruptcy. 
The next set of results characterizes the entrepreneur's joint choice of governance system and scale of investment. We find that the optimality of the insider or outsider governance system is a function of both the characteristics of the embedding economy as well as the nature of the technology. When the degree of development of markets $(M)$ is low relative to the quality of the institutions $(\lambda)$, the insider system is more likely to dominate the outsider system for a given technology. This is not surprising as relatively less-developed markets make the outsider system less effective in reducing agency costs and therefore generate lower firm value net of agency costs, relative to the insider governance system. Economies with relatively high quality of institutions are able to better control agency costs through insider governance systems and are more likely to adopt them.

However, when the degree of development of markets $(M)$ is above a threshold value (determined as a function of the quality of institutions), then the optimality of the governance system depends also on the nature of the firm's technology. When the productivity of the technology $\eta$ is high, the Pareto-optimal scale of investment $\left(I^{*}\right)$ is large. An interesting difference emerges between the insider and outsider systems as to their relative effectiveness at different scales of investment. Though agency costs increase with the scale of investment under both governance systems they increase at an increasing rate under the insider system, and at a decreasing rate under the outsider system. This difference in the sensitivity of the agency cost structure to the investment scale, makes the outsider systems optimal when the scale of investment, to be undertaken is high. Larger scales of investment are optimal for technologies with higher productivity. For a given economy ( $\lambda, M)$, the entrepreneur is likely to choose the

\footnotetext{
${ }^{6}$ This problem is similar in spirit to the joint solution of optimal scale of investment and optimal capital structure that is solved in Jensen and Meckling (1976), where both debt and equity give rise to agency costs increasing the investment level.
} 
outsider governance systems when the productivity of the technology is high and insider governance systems when the productivity of the technology is low.

The better performance of outsider systems with technologies that require a large scale of investment, and that of insider systems with technologies that are optimally implemented at small scales, is at the crux of the results in this paper. The intuition for this is that for technologies, which are implemented at small scale, the external financing that can be raised without agency costs is sufficient to implement the Pareto-optimal scale of investment. Therefore, for a range of technologies with low investment scale, the alignment mechanisms work very well in reducing or eliminating agency costs. As the scale is increased, the external financing required increases, and even with full ownership, the agency costs begin to increase rapidly. On the other hand, the outsider systems solve the agency problem in a probabilistic fashion (the raider appears and succeeds only with a certain probability). However, the scale of investment does not adversely affect the effectiveness of the takeover system. At large levels of investment, the agency costs in the outsider system increase slowly and at a declining rate.

The model generates several testable cross-sectional and inter-temporal predictions. For a given economy $(\lambda, M)$, the firms with technologies that can be implemented at relatively small scales may have opted for insider systems of corporate governance. In the same economy, firms with high-productivity technologies that require high scales of implementation may opt for an outsider system of governance. Such a cross-sectional variation in the governance systems of different firms as a function of the scale of its investment is a testable relationship. A further implication is that firms with similar technology will tend to have similar governance structure across economies with different characteristics. For example, industries with large investment scale and growth will tend to have outsider governance structures in all economies with developments of markets above a certain threshold. 
Inter-temporal implications of the model are consistent with evidence related to firms going public and other firms implementing going-private transactions. A given firm whose optimal investment scale is small may be optimally governed by an insider system with concentrated ownership. In time, growth in its investment opportunities may require a larger scale of investment that implies that it should optimally switch to an outsider governance system. This would require the firm to go public with a diffused ownership structure. Similarly, a firm with a stable mature technology may find that its external financing needs have decreased due to the high levels of internal financing that has accumulated through operations over time such that it may optimally switch from an outsider system to an insider system with concentrated insider ownership. This will explain its going-private transaction (such as an LBO).

The model also throws light on the persistence of governance systems and potential convergence. Consider an economy ( $\lambda, M)$, which experiences growth in the productivity of its technology. As the technology becomes more productive and has to be implemented at larger and larger scales, many firms may change from an insider system of governance to an outsider system of governance. This can happen even if the characteristics of the economy remain unchanged as long as the markets are developed above a certain threshold. Here, the convergence of the governance systems to outsider systems is driven by growth. Our result of a growth-driven convergence to outsider systems across different countries is different from the alternative theories proposed in the literature. ${ }^{7}$

\footnotetext{
${ }^{7}$ Several researchers have argued that exogenous legal and political factors have induced a path dependence that has deterred financial systems from converging to an efficient one. For example, Bebchuck and Roe (1999) argue that parties exercising control in firms have influenced lawmakers to come up with inefficient law that allows them to increase the private benefits that they extract. (These influential parties would be managers in the outsider system and controlling insider shareholders in the insiders system). These influences would induce a path dependence that can slow down convergence to the efficient systems. Roe (1994) argues that the development towards dispersed ownership in the U.S. was fostered by political movements leading to regulatory restrictions on strong financial institutions. This might have hindered sufficient capital accumulation and caused the ownership concentration in the U.S to be too low. In contrast, LLSV(1998) and LLS(1999) have argued that viability of dispersed ownership
} 
The rest of the paper is organized as follows. In Section 1 we discuss the structure of the basic model. Section 2 examines the characteristics of the optimal governance system, Section 3 analyzes the entrepreneur's joint decision of choice of investment scale and governance structure, Section 4 discusses empirical implications and Section 5 concludes.

\section{THE MODEL}

In this section we introduce the basics of the model. The entrepreneur has the following technology at date $t=0$. The technology consists of a project that can be undertaken at different scales of investment $I, I \geq 0$. The outcome is random with the payoffs being $H(I)$ in the successful state and zero in the unsuccessful state. For any level $I$, the project can be implemented in two ways. A good (bad) implementation produces probability of success $\alpha_{g}\left(\alpha_{b}\right)$, where $0<\alpha_{b}<\alpha_{g} \leq 1$. Further denote $\rho=\alpha_{g}-\alpha_{b} . H(I)$ is a concave increasing function of $I$ and takes the form $H(I)=\theta I^{\eta}$, where $\theta$ is a large positive parameter, and $\eta$, $0<\eta<1$, is an index of productivity of the technology. In particular, if $\alpha_{g} H(I)-I$ attains its maximum at $I^{*}$, then we assume that $\theta$ is large enough such that $\alpha_{g} H(I)-I$ is positive for all $I$ less than or equal to $I^{*}$.

\subsection{The Agency Problem and the Quality of Institutions}

The entrepreneur incorporates the firm, and hires a manager to implement the technology. By assumption, the manager cannot finance the required investment $I$ from his personal wealth, and raises it by selling claims to outside investors to finance the investment. ${ }^{8}$

requires strong shareholder protection under the law. Absence of adequate legal protection (e.g., in Civil law countries) have caused the ownership structure to be inefficiently too concentrated.

${ }^{8}$ In our model, we assume that the entire investment I is financed by selling claims to outside investors. We couild have modeled the entrepeneur as investing his own capital, A and only raising the residual (I-A) externally. As is common in models of corporate finance the agency costs in our model are increasing in the amount of external 
Now we introduce the managerial agency problem through the following simple device: The manager derives differential private benefits of control from the two implementations of the technology. For simplicity, we will standardize the private benefits from the good project to be zero and that from the bad project to be $B>0$. Now the project, which maximizes the managerial objective of the sum of his private benefits of control and the value of his personal holding in the project cash flows, can be the bad project. The level of private benefits $B$ parameterizes the severity of the agency problem and the managerial incentives to implement the bad project. The level of private benefits, $B$, that will be realized is not known to the entrepreneur at date $t=0$; he only has a probability distribution of $B$ as described in the next paragraph.

The effectiveness of the legal system in the economy and the quality of its institutions in enforcing contracts will determine the admissible set of enforceable contracts available. This in turn will determine what is left to the discretion of the manager. High quality institutions, which can enforce a full menu of forcing contracts, may leave very little to the discretion of the manager resulting in little agency costs. ${ }^{9}$ We model the severity of agency problems to be a function of the quality of the institutions in the economy in which the firm operates. We will use $\lambda, 0 \leq \lambda \leq 1$, to be an index of the quality of institutions in the economy, where the higher the quality of institutions, the smaller is $\lambda$. The severity of the agency problems in our setup is modeled to be higher with a lower quality of institutions (higher $\lambda$ ) and higher with a larger scale of operations (higher $H(I)$ ). This is captured by modeling the support of the probability

financing required. Our assumption that the entire investment is financed externally simplifies the model structure without loosing any essential insights. All our results involving the scale of investment $I$ can be readily reinterpreted in terms of (I-A) the external financing raised.

${ }^{9}$ These institutions would include the legal system in the economy as well as financial institutions such as banks. Our parameterization allows for different degrees of development of institutions and markets in a given economy. We believe that legal regimes and basic banking institutions, whether well developed or not, are available in most countries. In contrast, sophisticated institutions like those supporting financial markets are not universal. 
distribution of private benefits to be an increasing function of both $\lambda$ and $H(I)$. The private benefits are uniformly distributed on $[0, \lambda \rho H(I)] .^{10}$

\subsection{Governance Mechanisms}

In an economy with a quality of institutions indexed by $\lambda$, an entrepreneur planning to undertake a level of investment I faces an agency problem as described in the previous paragraph. The manager in charge would receive a draw of private benefits B from the probability distribution uniform over $[0, \lambda \rho H(I)]$ which in turn may distort his incentives such that he implements the bad project. Now the entrepreneur looks to the mechanisms of corporate governance and designs an optimal governance system to minimize the agency costs resulting from managerial incentive problems. We model explicitly two of the commonly used mechanisms of corporate governance: (1) aligning the manager's incentives with that of shareholders, and (2) takeovers.

The first mechanism serves to align the manager's interests with those of shareholders. We model this class of governance mechanisms based on managerial incentive contracts simply through the device of a managerial compensation structure consisting of a salary $S$ and a fraction ' $a$ ' of the equity of the firm. This modeling choice is motivated by empirical and theoretical considerations. ${ }^{11}$ The empirical literature documents that the bulk of the pay-performance sensitivity in managerial contracts comes from managerial ownership of equity and stock options (see, e.g., Jensen and Murphy (1990) and Murphy (1998)). In our model, the fraction of equity owned by the manager captures the degree of alignment of his interests with that of the shareholders. Although we do not explicitly model bonuses and executive stock options, it can

\footnotetext{
${ }^{10}$ We have chosen $\mathrm{H}(\mathrm{I}) \rho$ as the relevant maximum level of private benefits because at that level of private benefits the bad project becomes the socially optimal choice.

${ }^{11}$ The theoretical and empirical literature on incentive contracts, is vast and too numerous to be cited. See Murphy (1998) for a recent survey on managerial compensation issues.
} 
be shown theoretically that in the context of the agency problem of our model, this is without loss of generality. ${ }^{12}$ Independent of his ownership in the firm, the manager is in control of the project choice.

Managerial ownership mitigates agency problems as the manager chooses the bad project only when the private benefits $B$ are sufficiently large to offset the incremental value of his share of the higher cash flows from the good project. For low realized values of $B$, the manager will forego the private benefits and choose the good project. Let $B_{1}(a, I)$ be the cutoff such that for all value of $B \leq B_{1}(a, I)$ the manager chooses the good project, and for all $B>B_{1}(a, I)$ he chooses the bad project. $B_{1}(a, I)$ increases in managerial ownership (For further details see 2.1).

Takeovers are the second corporate governance mechanism that we consider. A great deal of theory and evidence support the view that takeovers are an important corporate governance mechanism (in the US). ${ }^{13}$ Discipline by takeovers takes the form of a raider emerging with a probability $\phi$, if the manager has implemented the bad project, accumulating a controlling fraction of the votes and implementing the good project. This probability, $\phi$, is a function of (1) the ease of takeovers in that economy, which in turn, is a function of the development of financial markets, (2) the fraction of shares owned by the manager and, (3) the degree of entrenchment of the manager. If the manager has implemented the bad project,

\footnotetext{
${ }^{12}$ Given the two-state cash-flow function for the firm, the most general structure of managerial compensation can be represented by a tuplet of wages for the manager, one for the high state and one for the low state. Any such feasible tuplet of payoffs for the manager that can be paid from the firm's cash flows can be replicated through a combination of a salary and an appropriate level of equity ownership. In this sense there is no loss in generality in restricting our managerial compensation to be the sum of a fractional ownership of equity and salary. More generally, in any two-state agency problem, it can be shown that an affine compensation structure subsumes the most general compensation structures possible.

${ }^{13}$ See Manne (1965) and Scharfstein (1988)) for the role of takeovers in solving managerial agency problems. There is evidence that takeovers increase the combined value of the target and acquiring firm (Jensen and Ruback (1983)) and that takeover targets are often poorly performing firm (Morck, Shleifer and Vishny (1988a)). Jensen (1986) has argued that takeovers can solve the free cash flow problem, since they often lead to distribution of the firm's profits to investors.
} 
takeovers happen with probability $\phi(a)=\operatorname{Max}\left(M-\frac{M}{\psi} a, 0\right)$, where $M, 0<M \leq 1$, is the ease

of takeovers in the economy, $a$ is managerial ownership and $\psi$ is the minimum level of managerial ownership at which takeover probability becomes zero. We will index economies $(\lambda, M)$, where $\lambda \in(0,1)$ captures the quality of institutions in the economy and $M \in(0,1)$ captures the underlying effectiveness of takeovers in the economy.

\subsection{The Entrepreneur's Problem}

In the absence of agency costs, the entrepreneur's problem is simply to implement the scale of investment to maximize firm value. Let $I^{*}$ be the Pareto-optimal investment that maximizes firm value $V(I)=\alpha_{g} H(I)-I$. In a world with complete contracting, the entrepreneur will stipulate in the managerial contract that the good implementation of the technology at scale $I^{*}$ be undertaken.

Lemma 1: The optimal level of investment is $I^{*}=\left(\alpha_{g} \theta \eta\right)^{\frac{1}{(1-\eta)}}$ and $V\left(I^{*}\right)=\frac{(1-\eta)}{\eta} I^{*}$.

Proof: $I^{*}=\arg \max \left(\alpha_{g} \theta I^{\eta}-I\right)$. First order condition, $\alpha_{g} \theta \eta I^{\eta-1}=1$ implies $I^{*}=\left(\alpha_{g} \theta \eta\right)^{\frac{1}{(1-\eta)}}$ and $V\left(I^{*}\right)=\alpha_{g} \theta I^{* \eta}-I^{*}=\frac{(1-\eta)}{\eta} I^{*}$

However, in the presence of agency costs the entrepreneur's objective changes to maximizing firm value net of agency costs. As seen in the previous section and discussed in detail later, $B_{1}(a, I)$, the cutoff for private benefits beyond which the manager chooses the bad project, is a function of investment $I$, and managerial ownership $a$. Therefore, agency costs in equilibrium will be a function not only of the governance structure in place but also of the chosen scale of investment. The overall problem can now be summarized. Given the 
characteristics of the embedding economy $(\lambda, M)$ and the productivity of the technology $(\eta)$, the entrepreneur jointly picks the optimal governance system and the scale of investment to maximize $V(a, I)$, the firm value net of agency costs.

$$
V(a, I)=H(I) \alpha_{g}-I-L(a, I)
$$

where $L(a, I)$ is the loss in firm value due to agency costs at investment $I$ and managerial ownership $a$.

We solve the entrepreneur's overall problem in stages. First, we characterize the optimal governance structures that minimize agency costs for a given level of investment $I$. As shown in Section 2.2, only two governance configurations emerge as optimal. We then characterize the optimal investment associated with each governance structure. Finally, the entrepreneur overall problem is solved by comparing firm value net of agency costs under the two governance systems at their associated optimal investment level. We characterize this joint optimality of governance structures and its associated investment level over all possible economies $(\lambda, M)$ and technologies $(\eta)$.

The sequence of events is as follows: At date $t=0$, the entrepreneur decides on an investment level $I$ and hires a manager to implement the project. At this time, the entrepreneur knows the characteristics of the embedding economy $(\lambda, M)$, the project technology $\eta$ and the probability distribution of the private benefits. At this time the entrepreneur also chooses an ownership structure for the manager. The choice of ownership structure for the manager is equivalent to picking the optimal governance structure for the firm since the ownership structure determines the degree of alignment that he puts in place for the management, as well as $\phi(a)$, the takeover effectiveness (i.e., the probability with which a raider appears if the manager has chosen a bad project). At date $t=1$, the private benefits are revealed and the manager chooses 
the project. If the manager chooses the bad project, the raider emerges with probability $\phi(a)$

and implements the good project. At period 2, the cash flows are realized and claims are settled.

The sequence of events is as follows:

$\begin{array}{lll}\qquad & \downarrow & \downarrow \\ \mathrm{t}=0 & \mathrm{t}=1 & \mathrm{t}=2 \\ \text { - Entrepreneur chooses managerial } & \text { - Private benefits are revealed } & \bullet \text { Cash flows generated } \\ \text { ownership } a & \text { - Raises required financing } & \text { and all claims settled } \\ \text { - Entrepreneur chooses scale of investment } & \text { - Manager chooses project } \\ I & \text { - Raider arrives with probability } \phi(a) & \end{array}$

\section{THE OPTIMAL GOVERNANCE STRUCTURE}

For a given level of investment $I$, we can characterize the choice of the optimal corporate governance system, constituted from individual mechanisms, i.e., ownership and takeovers. It is simply the solution to the following design problem: The entrepreneur designs an ownership structure for the manager to whom the running of the firm is delegated. In designing this ownership optimally the entrepreneur takes into account that the severity of the agency problem (parameterized by $B$ ) will have a range of possible realizations. He also rationally anticipates the effect of managerial ownership on: (1) the manager's choice of implementation of the technology, and (2) the effectiveness of the takeover market in disciplining the manager. The corporate governance structure will therefore, be represented by an optimally chosen managerial ownership structure, and the resulting effectiveness of the takeover mechanism.

\subsection{Manager's Decision and the Characterization of Agency Costs}

The manager is assumed to be risk-neutral. We abstract from the "risk-aversion" of the manager, since it does not play any essential role in the agency problem that we model. The 
manager's objective is given as $a \times C F+S+$ private benefits, where $a$ is managerial ownership of the firm, $C F$ denotes the expected cash flows to equity holders and $S$ is his salary. ${ }^{14}$

The manager issues external claims to raise capital for investment. These claims could be debt or equity claims. We focus on the agency costs arising from the incentives of insiders deviating from those of all external investors. We abstract from issues of capital structure (or more generally security design), and agency problems arising from the conflict between debt holders and equity holders. Here we assume that he issues debt claims of an appropriate face value $F>0.15$

Lemma 2: Let $B_{1}(a, I)=a \rho H(I) M^{*}(I)$, where $M^{*}(I) \equiv 1-F_{g}(I) / H(I), F_{g}(I)=I / \alpha_{g}$. The manager chooses the bad project only if realized private benefits $B>B_{1}(a, I)$. For $B \leq B_{1}(a, I)$ the manager chooses the good project.

Proof: See Appendix.

$\left(1-M^{*}(I)\right)$ can be interpreted as an index of the extent of external financing required. It is the fraction of firm value sold to outsiders in return for the external financing. Its complement $M^{*}(I)$ is a measure of the effectiveness of the alignment mechanisms. See remark below

\footnotetext{
${ }^{14}$ In the above characterization of the entrepreneur's problem, we have chosen not to include explicitly the compensation $R$ paid to the manager, where $R=S+a V(a, I)$. $R$ is the sum of a salary $S$ and fractional ownership a in the firm. Compensation $R$ is dictated by the labor market for managers, and is independent of the ownership structure ' $a$ ' chosen by the entrepreneur. In the case where $a$ is large and $a V(a, I)>R, S<0$, i.e., the manager will have to make a payment $(a V(a, I)-R)$ into the firm. If $(a V(a, I)-R)$ is large, the pool of candidates available to be such a manager (or an insider) with a large ownership structure will be limited by the initial wealth required. In such a case a frequent candidate may indeed be the initial owner or the entrepreneur of the firm whose initial wealth includes substantial or full ownership in the firm.

${ }^{15}$ If it was financed by sale of equity, the appropriate fraction given to outsiders is determined by rationally anticipating the project choice to be implemented. This is similar to the determination of F, the face value of debt.
} 
equation 2. As $M^{*}(I)$ is declining in $I$, the external financing need $\left(1-M^{*}(I)\right)$ increases with $I{ }^{16}$ The manager's decision is shown in the figure below:

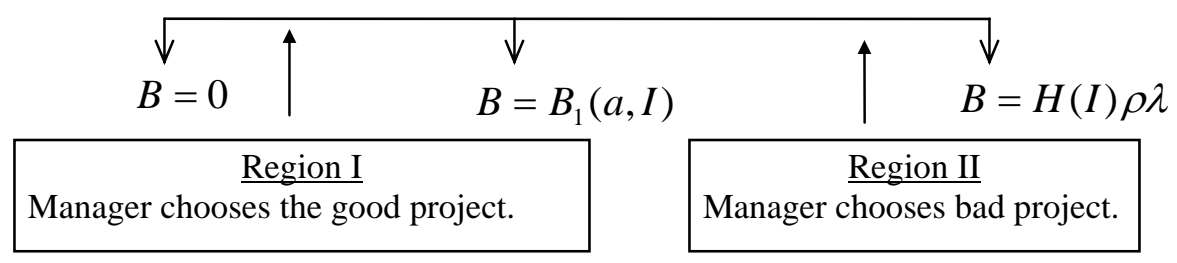

The probability with which the manager implements the good project, $P\left(B \leq B_{1}(a, I)\right)$, is endogenously determined by the level of managerial ownership, ' $a$ ', $\lambda$ and $M^{*}(I)$. As private benefits are uniformly distributed over $[0, \lambda \rho H(I)]$ (see section 1.1),

$$
P\left(B \leq B_{1}(a, I)\right)=\frac{a \rho H(I) M^{*}(I)}{\lambda H(I) \rho}=a \frac{M^{*}(I)}{\lambda}
$$

Remark 1: The probability that the manager will implement the good project is increasing in managerial ownership $a$, in the quality of institutions, and in the effectiveness of alignment mechanisms $M^{*}(I)$.

\subsection{Optimal Governance for a Given Scale of Investment}

In this section, we examine the optimal level of managerial ownership, i.e., the optimal governance structure, which will maximize firm value for a given level of investment. From equation (1), this is equivalently stated as choosing the governance structure to minimize agency costs $L(a, I)$ at investment level $I$.

Both mechanisms of corporate governance (managerial alignment and takeovers) are functions of managerial ownership, $a$. Increasing managerial ownership, $a$, increases

\footnotetext{
16 The derivative $\frac{\partial M^{*}(I)}{\partial I}=\frac{(1-\eta) I^{-\eta}}{\theta \lambda g}<0$
} 
alignment of the manager with shareholders but decreases the probability of takeovers. This trade-off between the effectiveness of the two interacting mechanisms is at the heart of the design of optimal corporate governance in this simple model.

Given that $B$ is random, the design of corporate governance is simply to choose a level of managerial ownership such that over all possible realizations of $B$, agency costs are minimized. For any managerial ownership $a$, the manager will choose the good project when the realized private benefits are less than the cutoff $B_{1}(a, I)$, i.e., when $B \leq B_{1}(a, I)$. For this range of realizations of private benefits, there are no agency costs. For $B>B_{1}(a, I)$, the good project gets implemented only with probability $\phi(a)$. The entrepreneur picks the ownership structure ' $a$ ', $0 \leq a \leq 1$ to minimize the agency costs $L(a, I)$.

$$
\underset{a}{\operatorname{Min}} L(a, I)=P\left(B>B_{1}(a, I)\right)(1-\phi(a)) H(I) \rho
$$

Substituting the value of $P\left(B>B_{1}(a, I)\right)$ from (2),

$$
L(a, I)=\left(1-a M^{*}(I) / \lambda\right)(1-\phi(a)) H(I) \rho
$$

We now characterize the optimal governance structures that emerge:

\section{Proposition 1:}

For a given scale of investment I, the optimal governance system will be one of the following two configurations:

1) A diffuse managerial ownership, $\hat{a}=0$, and an active takeover market with probability of takeover $\phi(0)=M>0$ or

2) A concentrated managerial ownership of $\hat{a}=\operatorname{Min}\left[1, \lambda / M^{*}(I)\right]$ where $M^{*}(I)=1-F_{g}(I) / H(I)$, and no role for takeovers.

Proof: See Appendix. 
The intuition underlying the proof can be seen as follows: Consider the case of zero managerial ownership. The governance mechanism here consists of only the takeover mechanism. As managerial alignment is zero, the manager has no incentive to implement the good project. An increase in managerial ownership from zero affects agency costs in two ways. An increase in managerial ownership increases his alignment and the probability of his implementing the good project. This reduces the agency costs incurred. However, an increase in managerial ownership also entrenches the manager and decreases the probability with which the takeover mechanism disciplines the manager when he chooses the bad project. This increases agency costs. The decrease in agency costs due to increased managerial alignment is captured by an increase in probability with which the manager implements the good project, i.e., by $P\left(B \leq B_{1}(a, I)\right)$ or $a M^{*}(I) / \lambda$. This increases linearly in managerial ownership. The increase in agency costs due to increased managerial entrenchment is captured by the expected costs of a reduced takeover probability. Takeover probability declines at a constant rate of $M / \psi$ as managerial ownership increases. However the expected increase in agency costs, arising from a declining takeover probability is also a function of managerial alignment. For example, if the manager is fully aligned, he will implement the good project with a high probability and the cost of a declining takeover probability would be small. On the other hand, at zero managerial alignment the impact of the same decline in takeover probability would be highest. The negative impact of reducing takeover probability on firm value decreases as managerial ownership increases, while the positive impact of increasing alignment on firm values stays constant. Therefore total agency costs are likely to first increase as managerial ownership increases from zero and then decline, giving rise to an agency cost function which is concave in managerial ownership $a$. The optimal ownership structure is therefore attained at extremal values. 
Remark 2: The characteristics of the optimal governance configuration in item (1) of the Proposition 1 captures the essential features of what has been called the outsider systems. We will refer to this configuration as the outsider governance system. Similarly, the optimal governance configuration in item (2) of the Proposition will be referred to as the insider governance system.

Given Proposition 1, we only need to consider the agency costs under either of the two configurations that arise. The agency cost under the outsider system is obtained by substituting $\hat{a}=0$, and $\phi(0)=M$ in equation (4). This is equal to

$$
L(0, I)=(1-M) H(I) \rho
$$

The agency cost under the insider system is similarly obtained by substituting $\phi(a)=0$ in equation (5). This is equal to

$$
L(\hat{a}, I)=\left(1-\hat{a} M^{*}(I) / \lambda\right) H(I) \rho
$$

The agency cost under the insider system in equation (6) can be zero or positive depending on the scale of investment $I$ that is undertaken. For low investment levels, such that $M^{*}(I)>\lambda$, the optimal management ownership, $\hat{a}=\lambda / M^{*}(I) \leq 1$ and the agency cost is zero. For larger investment levels, such that $\lambda>M^{*}(I), \hat{a}=1$ is the optimal ownership structure and the agency cost is positive. This is given by

$$
L(1, I)=\left(1-M^{*}(I) / \lambda\right) H(I) \rho
$$

Define as $\hat{I}$ as the cutoff level of investment where $M^{*}(\hat{I})=\lambda . \hat{I}$ can be characterized as

$$
\hat{I}=\left(\alpha_{g}(1-\lambda) \theta\right)^{\frac{1}{1-\eta}}
$$


Investment levels $I \leq \hat{I}$ can be undertaken with no agency costs under the insider system. Properties of agency costs under the insider and outsider systems for a given technology of productivity parameter $\eta$, are collected below:

Proposition 2: For a given technology $\eta$,

1) The agency cost under the insider system is zero for $I \leq \hat{I}$. For $I>\hat{I}$, the agency cost is increasing and convex in $I$, i.e., $\partial L(1, I) / \partial I>0$ and $\partial^{2} L(1, I) / \partial I^{2}>0$

2) The agency cost under the outsider system is increasing and concave in $I$ for $I>0$, i.e., $\partial L(0, I) / \partial I>0$ and $\partial^{2} L(0, I) / \partial I^{2}<0$

3) The marginal agency costs under the two systems are equal, i.e., $\partial L(1, I) / \partial I=\partial L(0, I) / \partial I$, at investment level $\tilde{I}$, where $\tilde{I}=\left(\alpha_{g}(1-M \lambda) \theta \eta\right)^{\frac{1}{1-\eta}}$

4) The total agency costs under the two systems are equal, i.e., $L(1, I)=L(0, I)$, at investment level $\overline{\bar{I}}$, where $\overline{\bar{I}}=\left(\alpha_{g}(1-M \lambda) \theta\right)^{\frac{1}{1-\eta}}$.

Proof: See Appendix.

As seen in Proposition 2 and Figure 1, (drawn for technologies with $\eta>(1-\lambda) /(1-M \lambda)$ ), agency costs under the insider system are zero for investment levels $I \leq \hat{I}$ and subsequently increase at an increasing rate with investment. ${ }^{17}$ Agency costs under the outsider system increase steadily with investment levels though at a decreasing rate. At investment level of $\tilde{I}$, the marginal increase in agency costs are equal under both governance systems. For all $I>\tilde{I}$, the marginal increase in agency costs are higher for the insider system than the outsider system.

${ }^{17}$ Figure 1 is drawn for technologies with high productivity, i.e., when $\eta>\frac{1-\lambda}{1-M \lambda}$. For this range of technologies, $\tilde{I}>\hat{I}$ 
At investment level $\overline{\bar{I}}$, the total agency costs incurred are the same under the two governance systems. Though the outsider system is not effective at small investment levels, it becomes increasingly effective at higher levels in comparison to the insider system. In particular, low investment levels, $I<\overline{\bar{I}}$ are implemented at lower agency costs under the insider system, while larger investment levels, $I>\overline{\bar{I}}$, are implemented at lower agency costs under the outsider system.

\section{CHOOSING THE OPTIMAL SCALE OF INVESTMENT}

As discussed earlier, the overall problem of the entrepreneur consists of determining an optimal scale of investment jointly with an optimal governance structure, which maximizes firm value net of agency costs. In the previous section, we characterized the only two configurations, which could arise as the optimal governance system for implementing a given scale of investment $I$. In this section, we will determine the optimal scale of investment, which will be implemented under the two governance systems. This will lead to a solution to the joint determination of optimal scale of investment and optimal governance system as detailed below.

Recall that Lemma 1 characterized the Pareto-optimal scale of investment for the technology $H(I)=\theta I^{\eta}$ as $I^{*}=\left(\alpha_{g} \theta \eta\right)^{\frac{1}{(1-\eta)}}$. If $I^{*} \leq \hat{I}$ then the pareto-optimal level of investment can be undertaken with no agency costs under the insider governance system. However, when $I^{*}>\hat{I}$ then undertaking investments above $\hat{I}$ involves a tradeoff. As the scale of investment is increased from $\hat{I}$ towards the optimal $I^{*}$ the agency costs under both governance systems increase (as seen from proposition 2). The optimal scale of investment is such that increase in cash flows from the project is offset by the increase in agency costs. In 
other words, given agency costs, the optimal investment level is attained where the marginal product from the technology is equal to the marginal agency cost. This level of investment maximizes firm value net of agency costs, i.e., $V(\hat{a}, I)=H(I) \alpha_{g}-I-L(\hat{a}, I)$, where $\hat{a}=0$ or 1 , is specified based on the governance system in place. As the marginal agency costs differ under the two governance systems, the optimal investment level and hence firm value net of agency costs will also differ under the two governance systems. After characterizing the optimal investment associated with each of the two governance systems, we compare firm value at the associated optimal investment levels net of agency costs under the two governance systems to obtain a final characterization of the entrepreneur's choice.

\subsection{Optimal Scale of Investment under the Outsider Governance System}

We now characterize the optimal investment under the outsider system with zero ownership and hence active takeovers. Agency cost under the outsider system is $L(I, 0)=(1-M) H(I) \rho$ as given in equation (5) and firm value net of agency cost is

$$
V(0, I)=H(I) \alpha_{g}-I-(1-M) H(I) \rho
$$

Let $I^{T}$ be the investment level, which maximizes firm value in (9). It is characterized below:

\section{Proposition 3:}

For a given degree of development of market, $M$, let $I^{T}$ be the investment level that maximizes firm value net of agency costs under outsider system:

1) $I^{T}=\left(\alpha_{T} \theta \eta\right)^{\frac{1}{1-\eta}}$ where $\alpha_{T}=\alpha_{g}-(1-M) \rho$

2) $I^{T}<I^{*}$.

3) $I^{T}$ is increasing in $M, \partial I^{T} / \partial M>0$. 
4) $V\left(0, I^{T}\right)=I^{T}\left[\frac{1}{\eta}-1\right]$

Proof: See Appendix.

As seen from Proposition 3, under the outsider governance system, an investment level of $I^{T}$ will be optimal and firm value net of agency costs will be $V\left(0, I^{T}\right)=I^{T}\left[\frac{1}{\eta}-1\right]$. As $I^{T}<I^{*}$, the investment undertaken under the outsider governance system is less than the Pareto-optimal investment. This is because increasing investment from $I^{T}$ to $I^{*}$ increases agency costs more than the marginal product, and therefore, reduces firm value net of agency costs. Further, the lower the development of markets (lower $M$ ), the larger are the agency costs associated with this governance structure and the greater is the under-investment. Only in the extreme case of completely developed markets, i.e., $M=1$ the outsider system solves the agency problems completely with $I^{T}=I^{*}$ and $V\left(0, I^{T}\right)=V\left(I^{*}\right)$.

\subsection{Optimal scale of investment under the Insider Governance System}

From Proposition 2, we know that under the insider system an investment level of $I \leq \hat{I}$ can be implemented with zero agency costs. Investments exceeding $\hat{I}$ would involve positive and increasing agency costs. Given this structure of agency costs in the insider system, whether investment would be at Pareto-optimal levels $I^{*}$, or at some lower levels would depend on the productive of the technology $\eta$ as well as the structure of agency costs determined by $\lambda$.

First, we characterize conditions under which the optimal investment $I^{*}$ can be undertaken in the insider system without any agency costs. For values of $\eta$ and $\lambda$ such that $I^{*}$ is less than $\hat{I}$, the optimal investment $I^{*}$ can be undertaken without any agency costs under the insider governance system. Comparing the values of $I^{*}$ (from Lemma 1) and $\hat{I}$ (from equation 
6) we obtain that whenever $\eta \leq(1-\lambda)$, we have $I^{*} \leq \hat{I}$, i.e., for small enough values of the productivity parameter $\eta, I^{*}$ will be small and can be implemented with managerial ownership of $\hat{a}=\lambda / M^{*}(I)$ in the insider system with no agency costs.

For all values of the productivity parameter, $\eta>(1-\lambda)$, undertaking an investment level $I^{*}$ involves positive agency costs even with full ownership. The manager's task is to choose the level of investment to maximize firm value net of agency costs, given the agency cost functions associated with the insider governance structure, i.e., to choose an investment level $I$ to maximize

$$
V(1, I)=H(I) \alpha_{g}-I-\left(1-M^{*}(I) / \lambda\right) H(I) \rho
$$

When $\eta>(1-\lambda)$, we have $I^{*}>\hat{I}$ and the manager faces the following choices: (1) either invest a level $\hat{I}$ which involves zero agency costs, or (2) invest an amount $I^{0}$, where $\hat{I}<I^{0} \leq I^{*}$ such that firm value net of agency costs in (10) are maximized. $I^{0}$ is the level of investment at which the marginal product of investment $\frac{\partial\left[\alpha_{g} H(I)-I\right]}{\partial I}$ equals the marginal increase in agency costs $\frac{\partial\left[\left(1-M^{*}(I) / \lambda\right) H(I) \rho\right]}{\partial I}$. There are two cases to consider depending on the value of the productivity parameter $\eta$. For relatively low values of $\eta>(1-\lambda)$, the marginal product of investment at $\hat{I}$ is strictly less than the marginal agency costs at $\hat{I}$, such that these two quantities are never equal for any $I>\hat{I}$. (As agency costs are increasing in $I$ for all $I \geq \hat{I}$ and the marginal product of investment is decreasing in $I$ for all $I \geq \hat{I}$, the two terms cannot be equal for any $I>\hat{I}$ ). This implies that the optimal investment for this case is $\hat{I}<I^{*}$. Here, even though investment at $\hat{I}$ involves underinvestment $\left(\hat{I}<I^{*}\right)$, the incremental agency costs from 
investing any higher level exceeds the marginal product of investment. In Proposition 4 which follows, we show that $I=\hat{I}$ is the optimal investment for values of $\eta$, where $(1-\lambda) \leq \eta \leq \frac{(1-\lambda)(1+k)}{(1+k-\lambda k)}$ and $k=\frac{\rho}{\lambda \alpha_{g}}$.

For larger values of $\eta$, i.e., $\eta>\frac{(1-\lambda)(1+k)}{(1+k-\lambda k)}$, the marginal product of investment at $\hat{I}$ exceeds the marginal agency costs at $\hat{I}$, and the optimal level of investment $I^{0}$ at which the two are equated is such that $\hat{I}<I^{0}<I^{*}$. For these $\eta$ values, $I=I^{0}$ is the optimal investment under the insider governance system. The above discussion regarding the optimal investment levels for the different values of $\eta$ and $\lambda$ are gathered in Proposition 4 below:

Proposition 4: For a given quality of institutions $\lambda, 0<\lambda<1$, define $k=\frac{\rho}{\lambda \alpha_{g}}, \eta_{1}=(1-\lambda)$, and $\eta_{2}=\frac{(1-\lambda)(1+k)}{(1+k-k \lambda)}$. The investment levels that will be optimally implemented under the insider governance system can be characterized as follows:

1) For $\eta<\eta_{1}$, the optimal investment is $I^{*}=\left(\alpha_{g} \theta \eta\right)^{\frac{1}{1-\eta}}$ and the firm value is $V\left(\lambda / M^{*}(I), I^{*}\right)=I^{*}(1 / \eta-1)$

2) For $\eta_{1} \leq \eta \leq \eta_{2}$, the optimal investment is $\hat{I}=\left(\alpha_{g}(1-\lambda) \theta\right)^{\frac{1}{1-\eta}}$ and the firm value is $V(1, \hat{I})=\hat{I}(\lambda /(1-\lambda))$

3) For $\eta_{2}<\eta<1$, the optimal investment level is $I^{o}=\left(\alpha_{o} \theta \eta\right)^{\frac{1}{1-\eta}}$, where $\alpha_{o}=\alpha_{g} \frac{(1+k-\lambda k)}{(1+k)}$. The firm value is $V\left(1, I^{o}\right)=I^{o}(1+k)(1 / \eta-1)$

Proof: See Appendix. 
As in the outsider system, there is under-investment when $\eta>\eta_{1}, \hat{I}, I^{0}<I^{*}$ and the Paretooptimal level of investment is not implemented. This under-investment reflects the tradeoff faced by the entrepreneur. Increasing investment beyond $I^{0}$ or $\hat{I}$, to $I^{*}$, will increase the marginal product but will also increase agency costs such that firm value net of agency costs is actually reduced. The weaker the institution in the economy (higher $\lambda$ ), the greater are the agency costs and the higher the under-investment $\left(I^{*}-I^{0}\right)$ or $\left(I^{*}-\hat{I}\right)$.

\subsection{Solution to the Entrepreneur's Overall Problem}

In propositions 3 and 4 , we characterized the optimal scale of investment that would be undertaken by an entrepreneur under the two corporate governance systems. In this section, we compare firm value net of agency costs for each governance system at its associated optimal investment level to characterize the solution to the entrepreneur's overall problem.

As seen from Proposition 4, for technologies with low productivity parameter $\eta<\eta_{1}$ insider governance systems with managerial ownership of $\hat{a}=\lambda / M^{*}\left(I^{*}\right) \leq 1$ are able to implement the Pareto-optimal investment $I^{*}$. The outsider system can only implement the investment level $I^{T}<I^{*}$, and is associated with agency costs. In this region characterized by low values of the productivity parameter $\eta$, i.e., $\eta<\eta_{1}$ (referred to as Region 1 ), the insider system clearly dominates the outsider system independent of the values of $\lambda$ and $M$.

For technologies with average productivity $\eta_{1} \leq \eta \leq \eta_{2}$, the insider system with managerial ownership of $\hat{a}=1$ implements an investment level $\hat{I}$ with firm value $V(1, \hat{I})=\hat{I}\left(\frac{\lambda}{1-\lambda}\right)$. The outsider system implements investment level $I^{T}$ with firm value 
$V\left(0, I^{T}\right)=I^{T}\left[\frac{1}{\eta}-1\right]$. The entrepreneur's choice of governance structure in this region will depend on a comparison of $V(1, \hat{I})$ with $V\left(0, I^{T}\right)$.

For technologies with productivity $\eta_{2}<\eta$, the insider governance system implements an investment level $I^{0}$ with firm value $V\left(1, I^{o}\right)=I^{o}(1+k)(1 / \eta-1)$. The outsider system implements an investment level $I^{T}$ with firm value $V\left(I^{T}, 0\right)=I^{T}\left[\frac{1}{\eta}-1\right]$. The entrepreneur's choice of governance structure in this region will depend on a comparison of $V\left(1, I^{0}\right)$ with $V\left(0, I^{T}\right)$

Now we characterize the solution to the entrepreneur's problem of jointly determining the optimal scale of investment and the optimal governance system for all possible firm technologies $\eta \in[0,1)$ in all possible economies $(\lambda, M)$.

\section{Proposition 5:}

Given economy $(\lambda, M)$ and technology $\eta$, proceed as follows: Compute the quantities $k, \eta_{1}, \eta_{2}, \alpha_{0}, \alpha_{T}, I^{*}, I, I^{0}$, and $I^{T}$ defined below:

$$
\begin{aligned}
& I^{*}=\left(\alpha_{g} \theta \eta\right)^{\frac{1}{(1-\eta)}}, \hat{I}=\left(\alpha_{g}(1-\lambda) \theta\right)^{\frac{1}{1-\eta}}, I^{T}=\left(\alpha_{T} \theta \eta\right)^{\frac{1}{1-\eta}} \text { where } \alpha_{T}=\alpha_{g}-(1-M) \rho, \\
& I^{o}=\left(\alpha_{o} \theta \eta\right)^{\frac{1}{1-\eta}} \text { where } \alpha_{o}=\alpha_{g} \frac{(1+k-\lambda k)}{(1+k)}, k=\frac{\rho}{\lambda \alpha_{g}}, \eta_{1}=(1-\lambda), \text { and } \eta_{2}=\frac{(1-\lambda)(1+k)}{(1+k-k \lambda)}
\end{aligned}
$$

1) For $\eta<\eta_{1}$, the insider governance system with managerial ownership of $\hat{a}=\lambda / M^{*}(I)$, no takeovers and investment level $I^{*}$ maximizes firm value. 
2) For $\eta_{1} \leq \eta \leq \eta_{2}$, the insider governance system with $\hat{a}=1$, no takeovers and investment level $\hat{I}$ is optimal when $M \leq M_{1}(\eta)$ where $M_{1}(\eta)=1-\frac{1}{k \lambda}+\frac{(1-\lambda)^{\eta} \lambda^{1-\eta}}{k \lambda \eta^{\eta}(1-\eta)^{1-\eta}}$. Outsider governance system with $\hat{a}=0$, takeover probability $M$ and investment level $I^{T}$ is optimal when $M>M_{1}(\eta)$.

3) For $\eta_{2}<\eta<1$, the insider governance system with $\hat{a}=1$, no takeovers and investment level $I^{0}$ is optimal when $M \leq M_{2}(\eta)$. Outsider governance system with $\hat{a}=0$, takeovers with probability $M$, and investment level $I^{T}$ is optimal when $M>M_{2}(\eta)$ where $M_{2}(\eta)=1-\frac{1}{k \lambda}+\frac{(1+k-k \lambda)}{k \lambda(1+k)^{\eta}}$.

Proof: See Appendix.

Proposition 5 is graphically represented in Figure 2. The intuition behind proposition 5 is relatively simple. The choice between the two governance systems is a function of: (1) the degree of development of markets relative to the quality of institutions in the economy (the relative value of $\mathrm{M}$ is displayed on the vertical axis of Figure 2), and (2) the productivity of the technology (the value of $\eta$ is displayed on the horizontal axis of Figure 2). The outsider system dominates in economies with relatively higher values of $M$, i.e., for a given productivity of technology $\eta$, the outsider system will be optimal only when the takeover effectiveness in the given economy $M$ exceeds a certain cut-off level $M(\eta)$. For low values of $\eta, \eta<(1-\lambda)$, the cut-off level $M_{0}(\eta)=1$, i.e., the insider system is optimal for all $M$; for $\eta_{1} \leq \eta \leq \eta_{2}$, the cut-off level is lower (i.e., $M_{1}(\eta)<1$ ), and for $\eta \geq \eta_{2}$, the cut-off is lower still, i.e., $M_{2}(\eta)<M_{1}(\eta)$. 
The relationship between the cutoff values $M_{1}(\eta)$ and $M_{2}(\eta)$ and the productivity of the technology $\eta$ can be summarized as follows:

\section{Corollary 1:}

1) Both $M_{1}(\eta)$ and $M_{2}(\eta)$ are decreasing in $\eta$.

2) $M_{2}(\eta)$ is convex in $\eta$. The sign of $\frac{\partial^{2} M_{1}(\eta)}{\partial \eta^{2}}$ depends on parameter values of $\lambda$ and $\alpha_{g}$.

\section{Proof: See Appendix.}

As the productivity of the technology gets larger and larger, the outsider system is more likely to be optimal. Not surprisingly, the greater is the development of markets relative to the quality of institutions in the economy, the more likely are outsider systems with diffuse ownership to have the lower agency costs. Further, as agency costs under the outsider systems increase at a decreasing rate with increase in investment levels (and increase in $\eta$ levels), the higher the scale of the project, the greater is the advantage of the outsider systems relative to the insider systems.

There is an alternative way of characterizing the results in Proposition 5 and Figure 2. In Proposition 5, the results specify $M$, the degree of development of markets required to make it optimal for a technology of productivity $\eta$ to choose the outsider system as the optimal governance structure and implement the corresponding optimal investment level $I^{T}$. An alternate way of viewing the results presented in Figure 2 is as follows: For a given economy $(\lambda, M)$, how would firms with different technologies, $\eta$, pick their optimal governance structure and investment level. The answer to this question can be expressed in terms of $\eta$ values of the firms in questions. For a given economy $(\lambda, M)$, if $\eta$ is lower than a cut-off level, then insider systems dominate. If $\eta$ exceeds a cut-off level then outsider systems are optimal. The cut-off 
levels are in general a function of the economy parameters $\lambda$ and $M$. The details are characterized below:

\section{Proposition 6:}

Given economy $(\lambda, M)$, and technology $\eta$, compute the following quantities $I^{*}=\left(\alpha_{g} \theta \eta\right)^{\frac{1}{(1-\eta)}}$, $\hat{I}=\left(\alpha_{g}(1-\lambda) \theta\right)^{\frac{1}{1-\eta}}, I^{T}=\left(\alpha_{T} \theta \eta\right)^{\frac{1}{1-\eta}}$ where $\alpha_{T}=\alpha_{g}-(1-M) \rho, I^{o}=\left(\alpha_{o} \theta \eta\right)^{\frac{1}{1-\eta}}$ where $\alpha_{o}=\alpha_{g} \frac{(1+k-\lambda k)}{(1+k)}, k=\frac{\rho}{\lambda \alpha_{g}}, \eta_{1}=(1-\lambda)$, and $\eta_{2}=\frac{(1-\lambda)(1+k)}{(1+k-k \lambda)}$

1) For $\eta<\eta_{1}$, the insider governance system with managerial ownership of $\hat{a}=\lambda / M^{*}(I)$, no takeovers and investment level $I^{*}$ maximizes firm value.

2) For $\eta_{1} \leq \eta \leq \eta_{2}$, the insider governance system with $\hat{a}=1$, no takeovers and investment level $\hat{I}$ is optimal when $\eta \leq \eta_{3}(M)$. Outsider governance system with $\hat{a}=0$, takeover probability $M$ and investment level $I^{T}$ is optimal when $\eta>\eta_{3}(M) . \eta_{3}(M)$ is implicitly characterized as the solution to $(1-\eta) \ln \left(\frac{1-\eta}{\lambda}\right)+\eta \ln \left(\frac{\eta}{1-\lambda}\right)=\ln \left(\frac{\alpha_{g}}{\alpha_{T}}\right)$

3) For $\eta_{2}<\eta<1$, the insider governance system with $\hat{a}=1$, no takeovers and investment level $I^{0}$ is optimal when $\eta \leq \eta_{4}(M)$. Outsider governance system with $\hat{a}=0$, takeover probability $M$ and investment level $I^{T}$ is optimal when $\eta>\eta_{4}(M)$, where $\eta_{4}(M)=1-\frac{\ln \left(\alpha_{T} / \alpha_{o}\right)}{\ln (1+k)}$

Proof: See Appendix. 
Proposition 6 is also graphically represented in Figure 2. For values of $M$ which exceeds $\rho /\left(\lambda \alpha_{g}+\rho\right)$ when $\eta$ is larger than $\eta_{3}(M)$ (or $\eta$ is larger than $\eta_{4}(M)$ ), then the outsider system is the optimal governance system and $I^{T}$ is the optimal investment level. Recall that the Pareto-optimal level $I^{*}(\eta)$ is monotonically increasing in $\eta$. This implies that technologies which are best implemented at large investment levels also have the outsider system as the optimal governance system. Technologies with low $\eta$ values, i.e., those which optimally require low scale of investment, will choose the insider system as their optimal governance system. As firms grow such that their productivity and optimal scale of investment increase they may switch from insider systems to outsider systems. Such a convergence in governance systems is motivated by growth in productivity.

The above model explains differences in governance systems observed within an economy (for any given value of $M$ and $\lambda$ ) in terms of the differences in the productivity of the technology $(\eta)$. It also explains differences in governance systems across countries in terms of the development of markets relative to the quality of institutions.

\section{EMPIRICAL IMPLICATIONS}

We have derived a number of results on the scale of investment and the choice of optimally designed governance systems as a function of economy characteristics $(\lambda, M)$ and technology characteristics $(\eta)$. Several new empirical implications are suggested by these results. Among these results, some help to explain existing empirical evidence, while others offer opportunities for further empirical work. Our results have testable implications for crosscountry differences in the prevalent corporate governance systems as well as across-firm differences in corporate governance and scale of investment in a given economy. Existing and 
new empirical proxies for $\lambda, M$ and $\eta$ can be used to test these implications. ${ }^{18} \mathrm{~A}$ few of these testable implications are discussed below:

Implication 1: Economies with relatively high quality institutions will have insider governance systems. Economies with relatively well-developed markets will have outsider governance systems.

This is a straight-forward implication of Proposition 5. When $M<\frac{\rho}{\lambda \alpha_{g}+\rho}$ (more likely to happen when degree of development of markets (M) is low or quality of institutions is high (low $\lambda$ )), the optimal governance systems is always the insider system. A further implication is that for technologies $\eta<\eta_{1}$, the optimal managerial ownership is $\hat{a}=\lambda / M^{*}(I)$ which declines as the quality of institutions increases, i.e., $\lambda$ decreases. Since this result does not hold for $\eta>\eta_{1}$, it is only partially consistent with the finding of La Porta, Lopez-de-Silanes, Shleifer (1999) that ownership concentration varies inversely with legal development.

However, besides implications on differences in choice of governance across countries, we develop many implications regarding cross-sectional and inter-temporal differences in choice of governance systems within a given economy.

Implication 2: In any given economy $(\lambda, M)$ with degree of development of markets above a threshold, technologies that are implemented at smaller investment scale will have insider governance structures while those that require larger investment scale will have outsider governance structures.

\footnotetext{
${ }^{18}$ Several empirical proxies for the effectiveness of the legal regime, degree of investor protection, and the degree of contract enforcement in different economies around the world have been constructed. See, e.g., LLSV(1998) and Demirguc-Kunt and Maksimovic (1998). A metric of ease of takeovers in an economy (proxy for M) can be constructed along the lines in Gompers, Ishii and Metrick (2001).
} 
The above implication emerges straight from Proposition 6. Technologies implemented at small investment scales, $\eta<\eta_{1}$, are optimally implemented under insider governance systems. This occurs even when the degree of development of markets $(M)$ is high and is consistent with the empirical fact that even in an economy like the U.S. (with well developed markets), a large fraction of small business has insider systems. Our model would predict that these businesses with insider governance would be businesses with small scale of investment.

The importance of scale of investment in the choice of governance system also has some interesting inter-temporal implications for changes in the governance system of a firm.

Implication 3: In any given economy $(\lambda, M)$, firms that have switched from insider to outsider governance structures are more likely to do so after experiencing a growth phase. Firms that have switched from an outsider to an insider governance structure (e.g., through a going private transaction) are more likely to have done so after a phase of slow down in growth.

As can be seen from Figure 2, an increase in productivity $(\eta)$ for a given degree of development of markets will tend to move firms to the right, making outsider governance structures optimal. This may explain significant changes in the governance structures over a firm life cycle, like the decision to go public. The model predicts that cross-sectional differences between firms in an economy as to when they go public (move from insider to outsider governance systems) can be explained by the productivity of their technologies. Start-ups with technologies experiencing rapid growth in productivity, and therefore requiring larger investment levels, will go public earlier.

The above implication also predicts changes in governance consistent with what has been observed in other countries. Even in countries, which on average have insider dominated governance systems firms with high productivity will adopt outsider governance systems. 
Similarities of governance structures across firms in industries (which share the same growth characteristics) irrespective of whether they are located in traditional insider system economies or not, is another testable prediction of the model. The model highlights that along with the nature of the economy, i.e., whether or not institutions are effective, it is equally important to take into account firm characteristics in particular productivity of the technology to determine the choice of the equilibrium governance structure. This is consistent with the development of the Neuer Market in Germany, where many high technology firms are accessing public equity markets rather than adopting the traditional insider governance system.

Further, the model's prediction that growth in productivity of technology will generate pressure to adopt outsider governance structure is consistent with the recent pressure to converge to the outsider governance structure in the face of increased globalization and adoption of internet-based technologies. However, this pressure to converge to outsider governance systems will be experienced by economies with sufficiently well developed markets. As seen from

Figure 2, economies with poorly developed markets $\left(M<\frac{\rho}{\lambda \alpha_{g}+\rho}\right)$ will never find it optimal to change to outsider governance systems. Therefore, in economies with sufficiently well developed markets you would find firms switching from concentrated ownership structures to diffused ownership structures and vice versa. Similarly, in economies with sufficiently well developed markets firms would optimally choose concentrated or diffuse ownership structures as a function of the productivity of the technology. Together these observations lead to the following prediction.

Implication 4: The cross-sectional and inter-temporal differences in ownership structures would be higher in economies with well-developed markets compared to economies without. 


\section{CONCLUSION}

In this paper, we develop a framework to explain the optimal choice of governance systems and investment levels in different economies as well as cross-sectional and intertemporal variations in these choices within the same economy. An important contribution of the paper is to endogenously derive the optimal investment and choice of governance system as a function of the characteristics of the embedding economy and that of the technology of the firm.

We find that only one of two governance configurations with some opposing features turn out to be optimal choices. In one system, referred to as an insider system, there is concentrated ownership, reliance on institutions, and no role for takeovers. The other system, which emerges as optimal, is characterized by dispersed ownership and an active role for takeovers, and is referred to as the outsider system. The two governance systems differ from each other in the nature of agency costs as well as in the optimal investment associated with them.

In particular, we find that when the scale of investment is small, insider systems with concentrated ownership are capable of implementing the Pareto-optimal level of investment with no agency costs. However, as the scale of investment and the amount of external financing increases, agency costs under both governance systems increases, and both systems are associated with under-investment i.e., the optimal investment levels implemented under the governance system will be less than the Pareto-optimal investment.

An important result of the paper is that when markets are relatively well developed, entrepreneurs with technologies with small scale of investment will opt for insider systems while those with high growth and large scale of investment will opt for outsider systems. The intuition of why the outsider systems perform better with technologies that require a large scale of investment, and the insider systems perform well with technologies that are optimally 
implemented at small scales is as follows: for small degrees of external financing, the alignment mechanisms work very well in reducing or eliminating agency costs. As the scale is increased gradually, although there may be positive agency costs, its rate of increase is still small.

However, beyond a certain scale, the agency costs under the insider governance systems begin to increase rapidly. On the other hand, the outsider systems only solve the agency problem in a probabilistic fashion (the raider appears and succeeds only with a certain probability). However, the scale of investment does not adversely affect the effectiveness of the takeover mechanism and the outsider system of governance. At large levels of investment, the agency costs in the outsider system increases slowly at a declining rate. Our results also have implications for changes in governance structures, which are caused by changes in the productivity of firm technologies. In economies where the degree of development of markets is sufficiently high to make outsider governance systems viable, growth in the technology of the firm may make it optimal for the firm to switch from an insider governance system to the outsider system.

The paper proposes a novel idea that the changes in governance systems of firms within an economy as well as systematic pressures on economies to change their characteristics arise from changes in the technology, in particular its productivity. This is distinct from the political theory of why governance systems change or do not change. Growth-based pressures for change in governance may help explain the recent trends of convergence towards more outside governance systems. 


\section{Appendix:}

\section{Proof of Lemma 2:}

The manager's payoff if he implements the good project is $a\left[\alpha_{g}(H(I)-F)\right]+S$. If he implements the bad project his payoff is $a\left[\alpha_{g}(H(I)-F)\right]+S$ with probability $\phi(a)$ and $a\left[\alpha_{b}(H(I)-F)\right]+S+B$ with probability, $(1-\phi(a))$. Let $B_{1}(a, I)$ be the cutoff such that for all value of $B \leq B_{1}(a, I)$ the manager chooses the good project. Let $F_{g}(I)=(I) / \alpha_{g}$, be the face value of debt the manager can raise when the debt-holders correctly anticipate that the manager will implement the good project. Incentive compatibility for the manager requires that the manager has no incentive to implement the bad project, subsequent to issuing debt of face value $F_{g}(I)$, for values of $B \leq B_{1}(a, I) . B_{1}(a, I)$ is the highest value of private benefits for which he chooses the good project and is given by

$$
a\left[\alpha_{g}\left(H(I)-F_{g}(I)\right)\right]=(1-\phi)\left[a\left[\alpha_{b}\left(H(I)-F_{g}(I)\right)\right]+B_{1}(a, I)\right]+\phi\left[a\left[\alpha_{g}\left(H(I)-F_{g}(I)\right)\right]\right]
$$

Equivalently, $B_{1}(a, I)=a \rho H(I) M^{*}(I)$, where $\rho=\alpha_{g}-\alpha_{b}$.

Q.E.D.

\section{Proof of Proposition 1:}

1) Agency cost function given in (4) is concave in the region $0 \leq a \leq \psi$, where $\frac{\partial^{2} L(a, I)}{\partial a^{2}}=\frac{-2 H(I) \rho M M^{*}(I)}{\psi}<0$. Agency costs are therefore minimized at $a=0$ or $a=\psi$. At $a=\psi, \phi(a)$ drops to zero, and stays at zero for all levels of managerial ownership $a, 1 \geq a \geq \psi$, i.e., takeovers play no role. In the region where takeovers play a role, (i.e., $0 \leq a \leq \psi$ ) agency costs are minimized at diffuse managerial ownership of $\hat{a}=0$.

2) In the region without takeovers $\psi<a \leq 1$, increase in managerial ownership increases alignment. However as the probability of takeovers stays constant at zero, total agency costs decline with increasing ownership, i.e., $L(\psi)>L(1)$. In absence of takeovers, managerial ownership $\hat{a}=\operatorname{Min}\left[1, \lambda / M^{*}\right]$ minimizes agency costs . 


\section{Proof of Proposition 2:}

1) Substituting for $\hat{a}=\frac{\lambda}{M^{*}(I)}$ for $I \leq \hat{I}$ in equation (6), we have $L\left(\frac{\lambda}{M^{*}(I)}, I\right)=0$. For $I>\hat{I}$, substituting for $\hat{a}=1$ and $M^{*}(I)=1-F_{g}(I) / H(I)$ in equation (6), gives us $L(1, I)=k\left[H(I) \alpha_{g}(\lambda-1)+I\right]$ and $\partial L / \partial I=k\left[H^{\prime}(I) \alpha_{g}(\lambda-1)+1\right]$ where $k=\rho / \alpha_{g} \lambda$. $\partial L / \partial I>0$ if $H^{\prime}(I) \alpha_{g}(1-\lambda)<1$. As in this range, $I>\hat{I}, \lambda>M^{*}(I)$, $H^{\prime}(I) \alpha_{g}(1-\lambda)<H^{\prime}(I) \alpha_{g}\left(1-M^{*}(\hat{I})\right)$. Substituting for $M^{*}(\hat{I}), H^{\prime}(I)$ gives us $H^{\prime}(I) \alpha_{g}(1-\lambda)<H^{\prime}(I) \alpha_{g}\left(1-M^{*}(\hat{I})\right)<1 . \frac{\partial^{2} L(1, I)}{\partial I^{2}}=k\left[H^{\prime \prime} \alpha_{g}(\lambda-1)\right]>0$. Agency costs under the insider system are increasing and convex in $I$.

2) Agency costs with outsider system from equation (5) are $L(0, I)=(1-M) H(I) \rho$. $\partial L(0, I) / \partial I=(1-M) \rho H^{\prime}>0$ and $\partial^{2} L(0, I) / \partial I^{2}=(1-M) \rho H^{\prime \prime}<0$. Agency costs under the outsider system are increasing and concave in $I$.

Derivations of:

3) $\tilde{I}$ is the investment level at which $\partial L(1, I) / \partial I=\partial L(0, I) / \partial I$, i.e., $k\left[H^{\prime} \alpha_{g}(\lambda-1)+1\right]=(1-M) \rho H^{\prime}$. Simplifying we get $H^{\prime}(\tilde{I})=1 / \alpha_{g}(1-M \lambda)$. Solving for $\widetilde{I}$ with $H(I)=\theta I^{\eta}$ we obtain $\tilde{I}=\left(\alpha_{g}(1-M \lambda) \theta \eta\right)^{\frac{1}{1-\eta}}$.

4) $\overline{\bar{I}}$ is the investment level at which $L(0, I)=L(1, I)$, i.e., $(1-M) H\left(\stackrel{\bar{I}}{)} \rho=k H(\overline{\bar{I}}) \alpha_{g}(\lambda-1)+k \overline{\bar{I}}\right.$. Solving for $\overline{\bar{I}}$ with $H(I)=\theta I^{\eta}$ gives $\overline{\bar{I}}=\left(\alpha_{g}(1-M \lambda) \theta\right)^{\frac{1}{1-\eta}}$

Q.E.D.

\section{Proof of Proposition 3:}

1) The first-order condition for maximizing $V(I, 0)$ in equation $(9)$, is $H^{\prime}\left(I^{T}\right) \alpha_{g}-1-(1-M) H^{\prime}\left(I^{T}\right) \rho=0$. Equivalently, $H^{\prime}\left(I^{T}\right)=\frac{1}{\alpha_{g}-(1-M) \rho}=\frac{1}{\alpha_{T}}>\frac{1}{\alpha_{g}}$.

Solving this yields the expression for $I^{T}$. Since $\alpha_{T}>\alpha_{b}>0, V(I, 0)$ is concave and $I^{T}$ is a maximum. 
2) Since $\alpha_{T}<\alpha_{g}$, direct comparison implies that $I^{T}<I^{*}$.

3) $\partial H^{\prime}\left(I^{T}\right) / \partial M<0$. As $M$ increases $\alpha_{T}$ increases, $H^{\prime}\left(I^{T}\right)$ decreases implying that $I^{T}$ increases.

4) Substituting for $I^{T}$ and $H\left(I^{T}\right)$ in equation (9) gives $V\left(I^{T}, 0\right)=I^{T}\left[\frac{\alpha_{g}}{\alpha_{T}} \frac{1}{\eta}-(1-M) \frac{\rho}{\eta \alpha_{T}}-1\right]$ $=I^{T}\left[\frac{1}{\eta}-1\right]$.

Q.E.D.

\section{Proof of Proposition 4:}

1) For $\eta \leq(1-\lambda), I^{*} \leq \hat{I}$ and $\hat{a}=\lambda / M^{*}(I) \leq 1$. As $L\left(\hat{a}, I^{*}\right)=0$ in this range, $V\left(I^{*}\right)=\alpha_{g} \theta \quad I^{* \eta}-I^{*}=(1-\eta) I^{*} / \eta$.

2) At $I=\hat{I}$, the marginal agency costs are $\frac{(1-\eta) \rho}{\lambda \alpha_{g}}$ while the marginal product is $\frac{\eta}{(1-\lambda)}-1$. The marginal agency costs are greater than the marginal product for $\eta \leq \eta_{2}$. Since the marginal product is decreasing in $I$ and the agency cost is increasing in $I$, there is no investment level $I^{o} \geq \hat{I}$, where the marginal product equals the marginal agency cost. This implies that $\hat{I}$ is the optimal level of investment.

3) For $\eta_{2}<\eta<1$, optimal investment $I^{o}$ is the level of investment, which maximizes firm value net of agency costs given in equation (10). The first order condition gives $-1+H^{\prime}\left(I^{o}\right)\left[\alpha_{g}+\rho(1-\lambda) / \lambda\right]-\rho / \lambda \alpha_{g}=0$. Simplifying, $H^{\prime}\left(I^{o}\right)=\frac{(1+k)}{\alpha_{g}(1+k-\lambda k)}=\frac{1}{\alpha_{0}}>\frac{1}{\alpha_{g}}$ for $\lambda<1$. Solving the first-order condition yields the expression for $I^{o}$. Substituting for $I^{o}$ in equation (10) gives us $V\left(1, I^{o}\right)=I^{o}(1+k)\left(\frac{1}{\eta}-1\right)$.

Q.E.D.

\section{Proof of Proposition 5:}

1) For $\eta<\eta_{1}, V\left(\frac{\lambda}{M^{*}(I)}, I^{*}\right)=V\left(I^{*}\right)>V\left(0, I^{T}\right)$. 
2) For $\eta_{1} \leq \eta \leq \eta_{2}$, insider systems dominate if $V(1, \hat{I})>V\left(0, I^{T}\right)$. Substituting for $V(1, \hat{I})$ and $V\left(0, I^{T}\right)$ and simplifying, we have $V(1, \hat{I})>V\left(0, I^{T}\right)$ when $M<M_{1}(\eta)$ where $M_{1}(\eta)=1-\frac{1}{k \lambda}+\frac{(1-\lambda)^{\eta}(\lambda)^{1-\eta}}{k \lambda \eta^{\eta}(1-\eta)^{1-\eta}}$. Alternatively, $V(1, \hat{I})<V\left(0, I^{T}\right)$ when $M>M_{1}(\eta)$.

3) For $\eta_{2}<\eta<1$, insider systems dominate if $V\left(1, I^{o}\right)>V\left(0, I^{T}\right)$. Substituting for $V\left(1, I^{o}\right)$ from Proposition 4 and $V\left(0, I^{T}\right)$ from Proposition 3 and simplifying, we have $V\left(1, I^{o}\right)>V\left(0, I^{T}\right)$ when $M<M_{2}(\eta)$ where $M_{2}(\eta)=1-\frac{1}{k \lambda}+\frac{(1+k-k \lambda)}{k \lambda(1+k)^{\eta}}$.

\section{Proof of Corollary 1:}

1) $\frac{\partial M_{1}(\eta)}{\partial \eta}=\frac{(1-\lambda)^{\eta} \lambda^{1-\eta}}{k \lambda \eta^{\eta}(1-\eta)^{1-\eta}} \ln \left[\frac{(1-\lambda)(1-\eta)}{\lambda \eta}\right] \cdot \frac{\partial M_{1}(\eta)}{\partial \eta}<0$ for $\eta>(1-\lambda)$, i.e., in the range $\eta_{1} \leq \eta \leq \eta_{2}$ which is under consideration. $\frac{\partial M_{2}(\eta)}{\partial \eta}=-\frac{(1+k-k \lambda)}{k \lambda} \times \frac{\ln (1+k)}{(1+k)^{\eta}}<0$.

2) $\frac{\partial^{2} M_{2}(\eta)}{\partial \eta^{2}}=(\ln (1+k))^{2} \frac{(1+k-k \lambda)}{k \lambda} \frac{1}{(1+k)^{\eta}}>0$.

$\frac{\partial^{2} M_{2}(\eta)}{\partial \eta^{2}}=\frac{(1-\lambda)^{\eta} \lambda^{1-\eta}}{k \lambda \eta^{\eta}(1-\eta)^{1-\eta}}\left[\left(\ln \left\{\frac{(1-\lambda)(1-\eta)}{\lambda \eta}\right\}\right)^{2}-\frac{1}{\eta(1-\eta)}\right]$. The sign depends on parameter values $\lambda$ and $\alpha_{g}$.

\section{Proof of Proposition 6:}

Q.E.D.

1) For $\eta<\eta_{1}, V\left(\frac{\lambda}{M^{*}(I)}, I^{*}\right)=V\left(I^{*}\right)>V\left(0, I^{T}\right)$.

2) For $\eta_{1} \leq \eta \leq \eta_{2}$, the insider governance systems dominate if $V(1, \hat{I})>V\left(0, I^{T}\right)$. Substituting for $V(1, \hat{I})$ and $V\left(0, I^{T}\right)$ and simplifying, we have $V(1, \hat{I})>V\left(0, I^{T}\right)$ when $(1-\eta) \ln \left(\frac{1-\eta}{\lambda}\right)+\eta \ln \left(\frac{\eta}{1-\lambda}\right)<\ln \left(\frac{\alpha_{g}}{\alpha_{T}}\right)$ or $\eta<\eta_{3}(M)$.

3) For $\eta_{2}<\eta<1$, insider systems dominate if $V\left(1, I^{o}\right)>V\left(0, I^{T}\right)$. Substituting and simplifying, this holds when $\eta<\eta_{4}(M)$ where $\eta_{4}(M)=1-\frac{\ln \left(\alpha_{T} / \alpha_{o}\right)}{\ln (1+k)}$.

Q.E.D. 


\section{REFERENCES}

Allen, F., and D. Gale, 1997, “Financial Markets, Intermediaries, and Intertemporal Smoothing,” Journal of Political Economy, 105.

Bebchuk, L., 1998, "A Theory of the Choice Between Concentrated and Dispersed Ownership of Corporate Shares,” Working Paper, Harvard University.

Bebchuk, L., 1999, “The Rent Protection Theory of Corporate Ownership and Control,” Working Paper, Harvard University.

Bebchuk, L., and M. Roe, 1999, "A Theory of Path Dependence in Corporate Ownership and Governance,” Stanford Law Review, Vol. 52, No. 1, 127-170.

Berle, A., and G. Means, 1932, “The Modern Corporation and Private Property”, New York, Macmillan.

Berglof, E., 1997, “A Note on the Typology of Financial Systems,” in Klaus J. Hopp and Eddy Wymeersch (EDS.) "Comparative Corporate Governance,” Berlin, Walter D. Gruyter, 151-164.

Boot, A.W.A., and A.V.Thakor, 1997, "Financial System Architecture,” Review of Financial Studies, 10, 693-733.

Bradley, M., C. A. Schipani, A.K. Sundaram and J.P. Walsh, 1999, “The Purposes and Accountability of the Corporation in Contemporary Society: Corporate Governance at Crossroads," Law and Contemporary Problems, Vol 62, No 3, 9-86.

Brickley, J., and C. James, 1987, “The Takeover Market, Corporate Board Composition, and Ownership Structure: The Case of Banking,” The Journal of Law and Economics (April), 161181.

Claessens, S., S.Djankov and L. Lang., 2000, "The Separation of Ownership and Control in East Asian Corporations,” Journal of Financial Economics 58, 81-112.

Claessens, S., S.Djankov, J. Fan and L. Lang., 2002, “Expropriation of Minority Shareholders in East Asia," Journal of Finance, forthcoming.

Demirguc-Kunt, A., and Maksimovic, V., (1998), “Law, Finance, and Firm Growth”, Journal of Finance, 53, 2107-2137.

Demsetz, H., and K. Lehn, 1985, "The Structure of Corporate Ownership: Causes and Consequences,” Journal of Political Economy, 93, 1155-77.

Diamond, D., 1984,” Financial Intermediation and Delegated Monitoring”, Review of Economic Studies, LI, 393-414. 
European Corporate Governance Network (ECGN), 1997, “The Separation of Ownership and Control: A Survey of 7 Countries Preliminary Report to the European Commission,” Vol 1-4, Brussels: European Corporate Governance Network.

Franks, J., and C. Mayer, 1994, “The Ownership and Control of German Corporations,” Working Paper, London Business School.

Gompers, P. A., “Optimal Investment, Monitoring, and the Stages of Venture Capita,” Journal of Finance 50 (1995): 1461-1489.

Gompers, P.A., J.L.Ishii, and A. Metrick, 2003, “Corporate Governance and Equity Prices,” Quarterly Journal of Economics (February).

Gorton, G., and F. Schmid, 2000, “Universal Banking and the Performance of German Firms,” Journal of Financial Economics, Vol. 58, 29-80.

Gorton, G., and M. Kahl, 1999, "Blockholder Identity, Equity Ownership Structures, and Hostile Takeovers,” Working Paper, University of Pennsylvania.

Grossman, S.J., and O.D. Hart, 1986, “The Costs and Benefits of Ownership: A Theory of Vertical and Lateral Integration,” Journal of Political Economy 94, 691-719.

Grossman, S.J., and O.D. Hart, 1988, “One-Share One-Vote and the Market for Corporate Control,” Journal of Financial Economics, 20, 175-202.

Harris, M., and A. Raviv, 1988, “Corporate Governance: Voting Rights and Majority Rules,” Journal of Financial Economics, 20, 203-235.

Harris, M., and A. Raviv, 1989, “The Design of Securities,” Journal of Financial Economics, 24, 255-287.

Hirshleifer, D., 1995, “Mergers and Acquisitions: Strategic and Informational Issues”, in Finance, Hand Books in Operations Research and Management Science, Vol. 9, North-Holland.

Hoshi,T., A. Kashyap, and D. Sharfstein, 1993, ”The Choice between Public and Private Debt: An Analysis of Post- Regulation Corporate Financing in Japan”, MIT Working Paper.

Jensen, M., 1986, "Agency Costs of Free Cash Flow, Corporate Finance and Takeovers," American Economic Review, 76, 323-29.

Jensen, M., and W. Meckling, 1976, “Theory of the Firm: Managerial Behavior, Agency Costs and Ownership Structure,” Journal of Financial Economics, 3, 305-60.

Jensen, M., and K. Murphy, 1990, “Performance Pay and Top Management Incentives,” Journal of Political Economy, 98, 225-63. 
Jensen, M., and R. Ruback, 1983, “The Market for Corporate Control: The Scientific Evidence,” Journal of Financial Economics, 11, 5-50.

John, K., and A. Kalay (1982), “Costly Contracting and Optimal Payout Constraints,” Journal of Finance, 457-470.

John, T.A., and K. John (1993), “Top-Management Compensation and Capital Structure,” Journal of Finance, 48, 949-974.

John, K., and S. Kedia, 2003, "Design of Corporate Governance: Role of Ownership Structure, Takeovers, Bank Debt and Large Shareholder Monitoring”, New York University Working Paper.

John, K., and L. Senbet, (1998), “Corporate Governance and Board Effectiveness,” Journal of Banking and Finance, 22,371- 403.

Kang, J., and A. Shivdasani, 1995, "Firm Performance, Corporate Governance, and Top Executive Turnover in Japan,” Journal of Financial Economics, 38, 29-58.

Kaplan, S., 1994, “Top Executive Rewards and Firm Performance: A Comparison of Japan and the United States,” Journal of Political Economy, 102, 510-46.

Kester, C.W., 1991,“Japanese Takeovers,” Harvard Business School Press, Boston, Massachusetts.

La Porta, R., F. Lopez-De-Silanes, and A. Shleifer, 1999, “Corporate Ownership Around the World,” Journal of Finance, 54, (April), 471-518.

La Porta, R., F. Lopez-De-Silanes, A. Shleifer, and R.W. Vishny, 1997, "Legal Determinants of External Finance”, Journal of Finance, 52, (July), 1131-1150.

La Porta, R., F. Lopez-De-Silanes, A. Shleifer, and R.W. Vishny, 1998, “Law and Finance”, Journal of Political Economy, 106, 1113-1155.

La Porta, R., F. Lopez-De-Silanes, A. Shleifer, and R.W. Vishny, 2002, “Investor Protection and Corporate Valuation”, Journal of Finance, forthcoming.

Manne, H., 1965, “Mergers and the Market for Corporate Control,” Journal of Political Economy, 75,110-26.

Morck, R., A. Shleifer, and R. W. Vishny, 1988a, "Characteristics of Targets of Hostile and Friendly Takeovers,” in Alan J. Auerbach (ed). Corporate Takeovers: Causes and Consequences, Chicago: University of Chicago Press, 1988.

Morck, R., A. Shleifer, and R. W. Vishny, 1988b, "Management Ownership and Market Valuation: An Empirical Analysis,” Journal of Financial Economics, 20, 293-315. 
Murphy, K.J., 1998, “Executive Compensation,” in O. Ashenfelter and D. Card (eds.), Handbook of Labor Economics, Volume 3, North-Holland.

Myers, S.C., 1977, “Determinants of Corporate Borrowing,” Journal of Financial Economics, 147-175.

Myers, S.C., 1999, “Financial Architecture,” European Financial Management, 5, 133-141.

Rajan, R., 1992, “Insiders and Outsiders: The Choice Between Relationship and Arms-Length Debt,” Journal of Finance, 47, 1367-400.

Reese, Jr., W.A, and M. S. Weisbach, 1999, "Protection of Minority Shareholder Interest, CrossListings in the United States, and Subsequent Equity Offerings, Working Paper, University of Illinois.

Roe, M., 1994, “Strong Managers Weak Owners: The Political Roots of American Corporate Finance,” Princeton University Press.

Scharfstein, D., 1988, “The Disciplinary Role of Takeovers,” Review of Economic Studies, 55, 185-99.

Shivdasani, A., 1993, Board Composition, Ownership Structure, and Hostile Takeovers,” Journal of Accounting and Economics, 16, 167-98.

Shleifer, A., and R. W. Vishny, 1986, “Large Shareholders and Corporate Control,” Journal of Political Economy, 94, 461-488.

Shleifer, A. and R. W. Vishny, 1997, “A Survey of Corporate Governance,” Journal of Finance, 52, 737-775.

Shleifer, A. and D. Wolfenzon, 2002, “Investor Protection and Equity Market,” Journal of Financial Economics 66, 3-27.

Smith, C., and J. Warner, 1979, “On Financial Contracting: An Analysis of Bond Covenants,” Journal of Financial Economics, 117-161.

Song, M. H., and R.A. Walkling, 1993, “The Impact of Managerial Ownership on Acquisition Attempts and Target Shareholder Wealth,” Journal of Financial and Quantitative Analysis, Vol. 28.

Stulz, R., 1988, “Managerial Control of Voting Rights: Financing Policies and Market for Corporate Control,” Journal of Financial Economics, 20, 25-54.

Zingales, L., 1995, “Inside Ownership and the Decision of go Public,” Review of Economic Studies, Vol. 62, 425-448. 


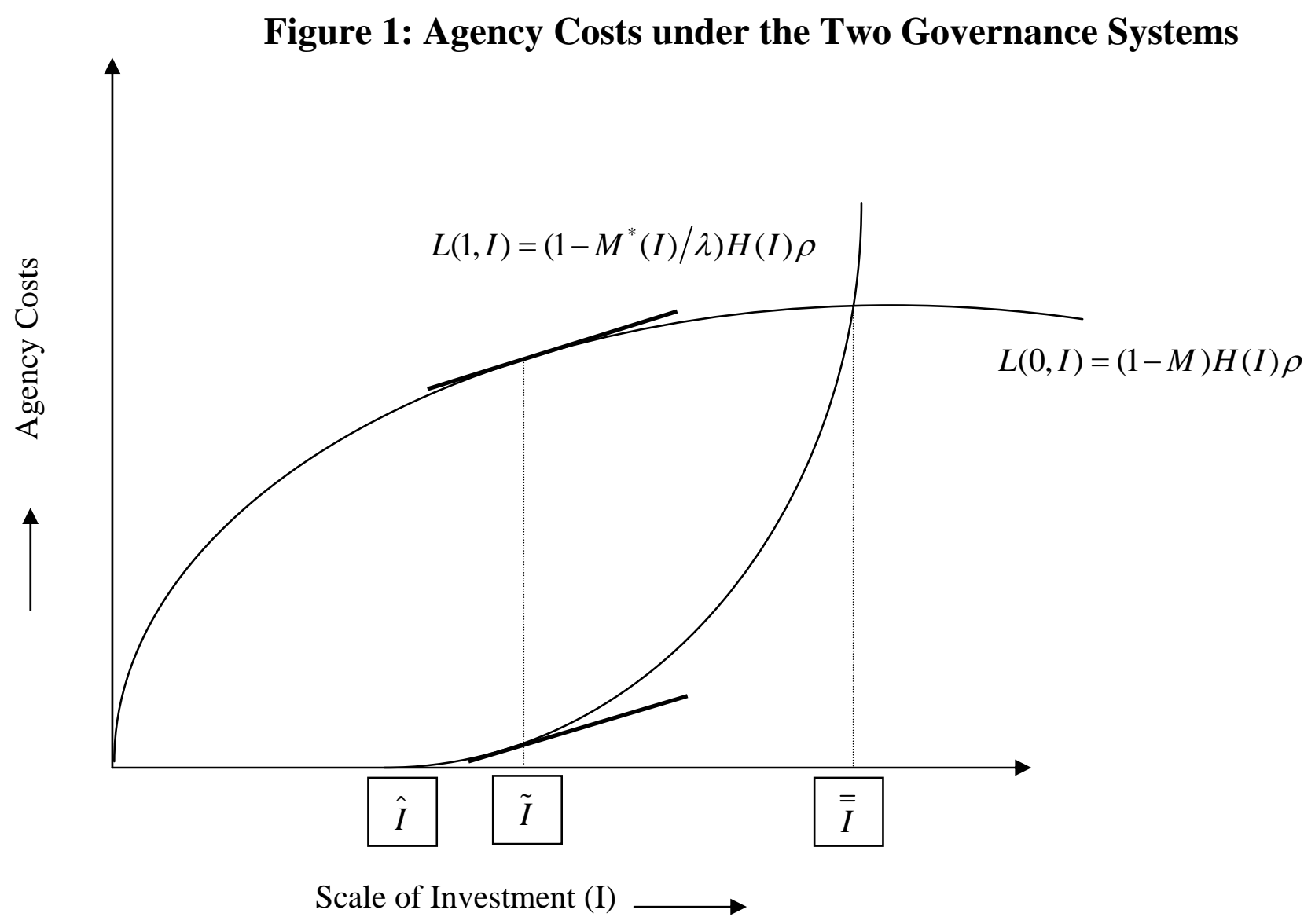

The figure displays the behavior of agency costs as a function of the scale of investment undertaken under the Insider and Outsider governance systems. The agency costs under the outsider governance system is non-zero for any level of investment and it is an increasing and concave function of investment. For the insider governance system the agency cost is zero for investment levels upto $\hat{I}$ and positive for higher levels of investment. The agency costs are an increasing convex function of investment. The displayed structure of agency costs imply that for technologies which are optimally implemented at large level of investment outsider governance system dominate. 
Figure 2: Optimal Corporate Governance Systems Characterized for Different Economies and Technologies

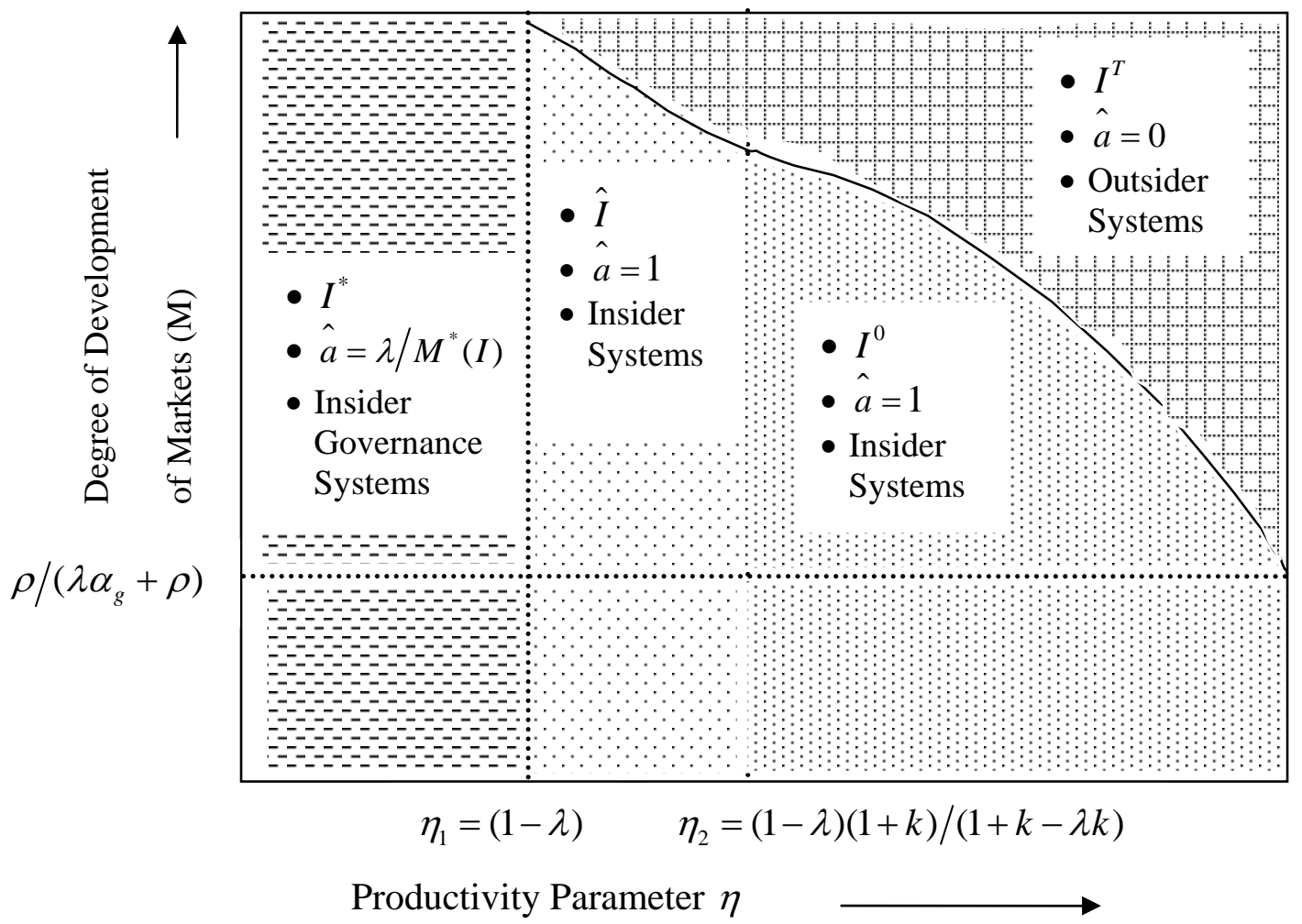

Figure 2 displays the optimal governance system and the optimal scale of investment undertaken as a function of economy wide parameters $M$ and $\lambda$, as well as the technology parameter $\eta$. When the degree of development of markets $M$ is below a threshold value, which depends on $\lambda$ the quality of institutions, then all technologies independent of the productivity parameter optimally use insider governance systems. For low productivity technologies $\eta<\eta_{1}$, the paretooptimal level of investment is implemented and there is zero agency costs under the insider governance system. For higher levels of the productivity parameter $\eta>\eta_{1}$, and when the degree of development of markets exceeds the threshold value, the optimal governance system may be the insider system or the outsider system depending on the productivity parameter $\eta$ and the degree of development of markets $M$. For large values of $\eta$ or for well-developed markets, high $M$, (represented by the cross-hatched region in the top right hand corner of figure) the optimal governance system is the outsider system with dispersed ownership. In the remainder of the region the insider governance systems dominate. Further details are displayed in the figure. 